International Journal of Trend in Scientific Research and Development (IJTSRD)

Volume: 3 | Issue: 3 | Mar-Apr 2019 Available Online: www.ijtsrd.com e-ISSN: 2456 - 6470

\title{
Proposed Wind Power System in Pyay District in Myanmar
}

\author{
Dr. Zarchi San, Daw Yin Aye Mon, Daw Lin Lin Phyu
}

Lecturer, Department of Electrical Power Engineering, Ministry of Education, Pyay Technological University (P.T.U), Pyay, Myanmar

\begin{abstract}
How to cite this paper: Dr. Zarchi San | Daw Yin Aye Mon | Daw Lin Lin Phyu "Proposed Wind Power System in Pyay District in Myanmar" Published in International Journal of Trend in Scientific Research and Development (ijtsrd), ISSN: 24566470, Volume-3 | Issue-3, April 2019, pp.347-349, URL: http://www.ijtsrd.co $\mathrm{m} /$ papers/ijtsrd227 82.pdf

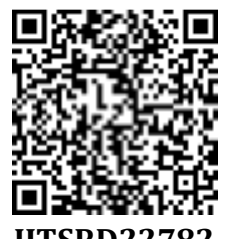

ABSTRACT

There are many aims for this paper such as to apply renewable energy for everyone in Myanmar, to supply electricity to rural areas not only offgrid but also ongrid and to construct wind turbines widely in costal region starting from this research. The proposed wind power system is $450 \mathrm{~W}$ in Pyay. This proposed system may be costed around US $\$ 1700$. As Bago Mountainuous Region is also situated in Pyay District, wind power can produce electricity. Moreover, 49 villages is no electricity among 567 villages. In this paper, five main components is expressed such as wind turbine, permagnet generator, rectifier, battery and inverter.

Copyright (C) 2019 by author(s) and International Journal of Trend in Scientific Research and Development Journal. This is an Open Access article distributed under the terms of the Creative Commons

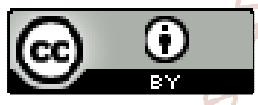
Attribution License (CC BY 4.0) (http://creativecommons.org/licenses/ by/4.0)

\section{INTRODUCTION}

Though the world's first wind turbine used to generate electricity was built by a Dane, Poul la Cour, in 1891, Myanmar Renewable Energy Association (MREA) said it is planning to build wind power plants in 27 locations in Yangon and Ayeyarwaddy regions and Rakhine and Chin states in 2014. The electrification rate in Myanmar is one of the lowest in Asia, at $57 \%$ in 2016 . The government aims to produce 2 percent of its electricity through renewable power in by 2020 and 9pc by 2030. The two parties signed a memorandum of agreement (MoA) for a wind turbine project in the Chaungtha area of Ayeyarwady Region, which will generate 30 megawatts of electricity, according to MOEP. In this paper, the proposed wind power system in Pyay is discussed. Though maximum supplied load of Pyay is now 72.06MW in 2018-19, it can be increased to $109.56 \mathrm{MW}$ in 2021-22. There are five main components that are wind turbine, permagnet generator, rectifier, battery and inverter in Figure 1.

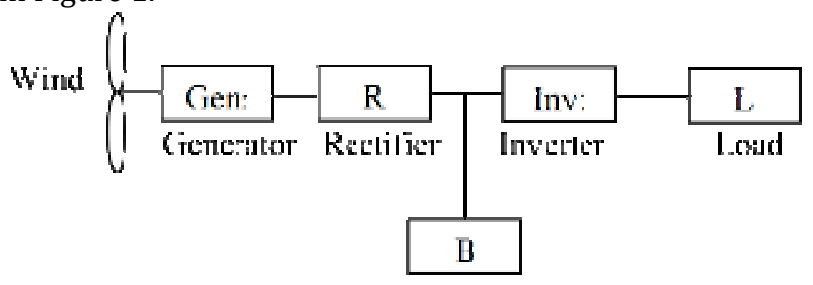

A. Wind Turbine

There are two types of wind turbine that are horizontal axis and vertical axis wind turbine. In this research, horizontal axis, 5 blades wind turbine is proposed. Pyay is located in $18.8^{\circ} \mathrm{N}, 95.2^{\circ} \mathrm{E}$ Latitude and Longitude so annual wind speed of Pyay is $2.6 \mathrm{~m} / \mathrm{s}$. It is measured at $10 \mathrm{~m}$ from NASA Source. Maximum power for this research can be calculated as following Equation (1).

$$
\mathrm{P}=\frac{1}{2} \times \rho \times \mathrm{A} \times \mathrm{v}^{3}
$$

$\mathrm{P}_{\omega}=$ the power in the wind (watts)

$\mathrm{P}=$ the air density $(\mathrm{kg} / \mathrm{m} 3)\left(\right.$ at $15^{\circ} \mathrm{C}$ and $1 \mathrm{~atm}$,

$\mathrm{P}=1.225 \mathrm{~kg} / \mathrm{m}^{3}$ )

$\mathrm{A}=$ the cross-sectional area through which the wind passes $\left(\mathrm{m}^{2}\right)$

$\mathrm{v}=$ windspeed normal to $\mathrm{A}(\mathrm{m} / \mathrm{s}), 1 \mathrm{~m} / \mathrm{s}=2.237 \mathrm{mph}$

The cut in wind speed is $3 \mathrm{~m} / \mathrm{s}$ and maximum power $450 \mathrm{~W}$ can be produced at wind speed $9 \mathrm{~m} / \mathrm{s}$. The wind power curve can be seen in Figure 2. LE-450 Wind Turbine, ALEKO WG 450A, Surface Power Technologies HAWT SP 460W are some of this rating available in the market. In Pyay, there are many places where is very near costal region to construct wind turbine.

Batict?

Figure1. Proposed Wind Power System 




Figure2. Wind Power Curve

The required tower height can get from Equation (2).

$$
\frac{\mathrm{v}}{\mathrm{v}_{\mathrm{o}}}=\left(\frac{\mathrm{H}}{\mathrm{H}_{\mathrm{o}}}\right)^{\alpha}
$$

$\mathrm{V}=$ the windspeed at height $\mathrm{H}$,

$\mathrm{v}_{0}=$ the windspeed at height $\mathrm{H}_{0}$ (reference height of $10 \mathrm{~m})$,

$\alpha=$ the friction coefficient

This wind turbine can produce the maximum power at the height of tower $650 \mathrm{~m}$.

\section{B. Generator Consideration of Wind Power System}

In comparison to induction generator, the use of synchronous generator is advantageous since they are selfexcited machines and the pole pitch of the machine can be smaller. It is generally favored in newer smaller scale turbine designs, since it allows for higher efficiency and smaller wind turbine blade diameter. The primary advantage of permanent magnet synchronous generator (PMSG) is that they do not require any external excitation current. To calculate the speed of generator and gear ratio, Equation 3 and 4 are expressed.

$$
\mathrm{rpm}=\frac{\mathrm{TSR} \times 60 \times \mathrm{v}}{\pi \times \mathrm{D}}
$$

$\mathrm{rpm}=$ the rotor speed, revolutions per minute

$\mathrm{D}=$ the rotor diameter $(\mathrm{m})$

$\mathrm{v}=\quad=$ the wind speed $(\mathrm{m} / \mathrm{s})$ upwind of the turbine

$$
\text { Gear ratio }=\frac{\text { Generator } \mathrm{rpm}}{\text { Rotor } \mathrm{rpm}}
$$

The speed of generator is $600 \mathrm{rpm}$ because of tip speed ratio is 3.4 and the result of gear ratio is 1.25 .

\section{LM 317 Voltage Regulator}

The output of generator is the input of voltage regulator and the output of voltage regulator goes to battery. There is an input, an output, and an adjustment terminal in LM 317. The external fixed resistor $\mathrm{R}_{1}$ and the external variable resistor $R_{2}$ provide the output voltage adjustment. $V_{\text {OUT }}$ can be varied from $1.2 \mathrm{~V}$ to $37 \mathrm{~V}$ depending on the resistor values. The LM317 can provide over $1.5 \mathrm{~A}$ of output current to a load. The LM 317 voltage regulator is shown in Figure 3. The output voltage can be get by solving Equation (5).



Figure3. The LM317 three-terminal adjustable positive voltage regulator

$$
\mathrm{V}_{\text {out }}=1.25\left(1+\frac{\mathrm{R}_{2}}{\mathrm{R}_{1}}\right)+\mathrm{I}_{A D J} \mathrm{R}_{2}
$$

The output voltage of LM 317 is $12 \mathrm{~V}$ by substituting $R_{1}=$ $1 \mathrm{k} \Omega$ and $\mathrm{R}_{2}=10 \mathrm{k} \Omega$.

\section{Battery}

The overall cost of the lead-acid battery is low compared to Nickel-cadmium (NiCd), Nickel-metal hydride (NiMH) and Lithium-ion (Li-ion) batteries. Because of its least cost per Wh delivered over the life, the lead-acid battery has been the workhorse of the industry. Battery capacity, voltage and current ofcharging and discharging state are calculated as follows.

Charging voltage $=$ charging voltage per cell $\mathrm{x}$ number of cell $=2.25 \times 6=13.5 \mathrm{~V}$ (fully charged)

Discharging Voltage

$=$ discharging voltage per cell $\mathrm{x}$ number of cell $=1.75 \times 6=10.5 \mathrm{~V}$ (fully discharged)

Battery capacity $=\mathrm{Whr} /$ voltage $=400 / 12=30 \mathrm{Ah}$

Choose two parallel 12V 14Ah lead-acid battery.

Charge or discharge current, $\mathrm{I}=\mathrm{Ah} / \mathrm{hr}=28 \mathrm{Ah} / 7 \mathrm{~h}=4 \mathrm{~A}$

\section{E. Inverter}

An inverter is an electronic device or circuitry that changes direct current (DC) to alternating current (AC). The square wave inverter is one of the simplest waveforms among others such as pure sine wave inverter, modified sine wave inverter and is best suited to low-sensitivity applications such as lighting and heating. Square wave" is the term used when the electricity has a constant force, such as it has with DC but switches direction more or less instantly at the same kind of frequency as the normal grid supply (at 50 times per second). Component of the inverter circuit

1. Transistor (2N $3636 \& 3055)$ 4nos

2. Capacitor

2 nos

3. Resistor

2 nos

4. Center tapped Transformer (12-12/230V) 1nos

The following Figure 4 is used to change battery $12 \mathrm{~V}$ DC to $230 \mathrm{~V}$ AC load. In this Figure, $Q_{1}$ and $Q_{2}$ are used for oscillation. $\mathrm{Q}_{3}$ and $\mathrm{Q}_{4}$ are used to get the positive polarity and negative polarity. $R_{1}$ and $R_{2}$ are used for basing the $Q_{1}$ and $Q_{2}$ and $R_{3}$ and $R_{4}$ are used for basing the $Q_{3}$ and $Q_{4}$.

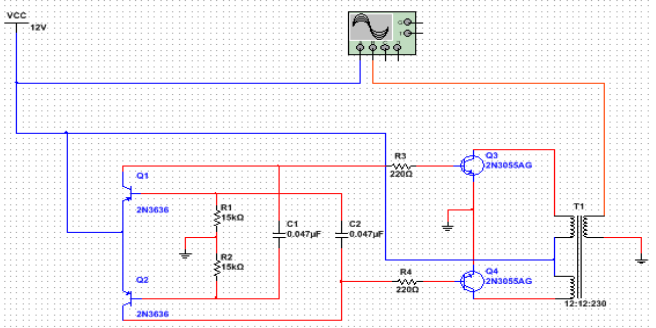

Figure4. 12 V DC to 230 V AC Inverter Circuit 


\section{Result}

The proposed wind power system in Pyay is $450 \mathrm{~W}$ with cut in $3 \mathrm{~m} / \mathrm{s}$ and rated wind speed $9 \mathrm{~m} / \mathrm{s}$. For this wind turbine, the number of blade is 5 and tower height is required to be $650 \mathrm{~m}$. Due to wind, generator can produce electricity with maximum power $450 \mathrm{~W}$. The primary advantage of permanent magnet synchronous generator (PMSG) is that they do not require any external excitation current. LM 317 voltage regulator is applied to get output voltage to be stable. Two numbers of $12 \mathrm{~V}, 14 \mathrm{Ah}$ battery is needed to back up supply while no wind blows. AC load can connect to $12 \mathrm{~V}-$ $230 \mathrm{~V}, 450 \mathrm{~W}$ inverter.

Table1. Main Components and Specifications

\begin{tabular}{|c|c|}
\hline Main Components & Specification \\
\hline Wind Speed & $3 \mathrm{~m} / \mathrm{s} \sim 9 \mathrm{~m} / \mathrm{s}$ \\
\hline No: of Blade & 5 \\
\hline Height of Wind Turbine & $650 \mathrm{~m}$ \\
\hline Generator & $450 \mathrm{~W}, 12 \mathrm{~V}$ \\
\hline Voltage Regulator Circuit & $\mathrm{LM} 317$ \\
\hline Battery & $12 \mathrm{~V}, 14 \mathrm{Ah}(2 \mathrm{No}:)$ \\
\hline Inverter & $450 \mathrm{~W}, 12 \mathrm{~V}-230 \mathrm{~V}$ \\
\hline
\end{tabular}

In Pyay, there are many mountains so wind turbine can be constructed. From NASA source, the annual wind speed is about $2.6 \mathrm{~m} / \mathrm{s}$. In this paper, $450 \mathrm{~W}$ wind turbine is disscussed and the rated wind speed is $9 \mathrm{~m} / \mathrm{s}$. As wind is not steady, the output is notconstant. LM 317 voltage regulator can regulate the output voltage. The following Figure 5 is simulation result of LM 317. The output voltage is about 10.2 $\mathrm{V}$ when the input is $12 \mathrm{~V}$. The resistors $\mathrm{R}_{1}$ and $\mathrm{R}_{2}$ are calculated.

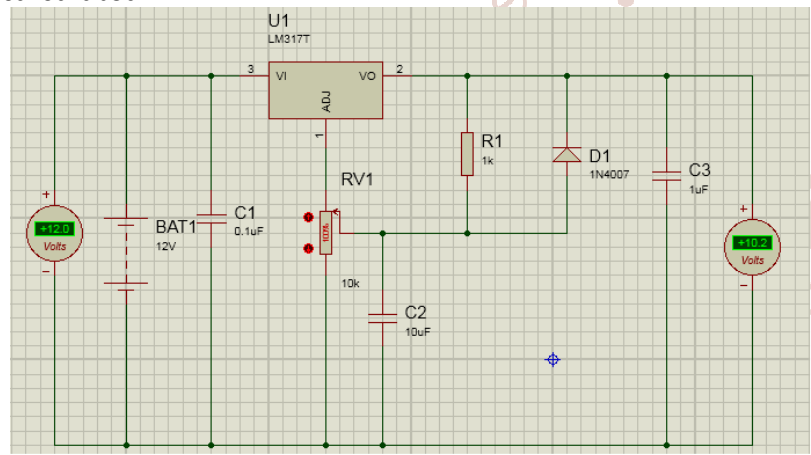

Figure5. Simulation Result of LM 317

To supply AC load, inverter is required and Figure 6 is simulation result of square wave output of inverter. The straight line with blue color is DC $12 \mathrm{~V}$ and the square wave with red color is for output $230 \mathrm{~V}$. Square wav is used when the electricity has a constant force, such as it has with DC but switches direction more or less instantly at the same kind of frequency as the normal grid supply (at 50 times per second).

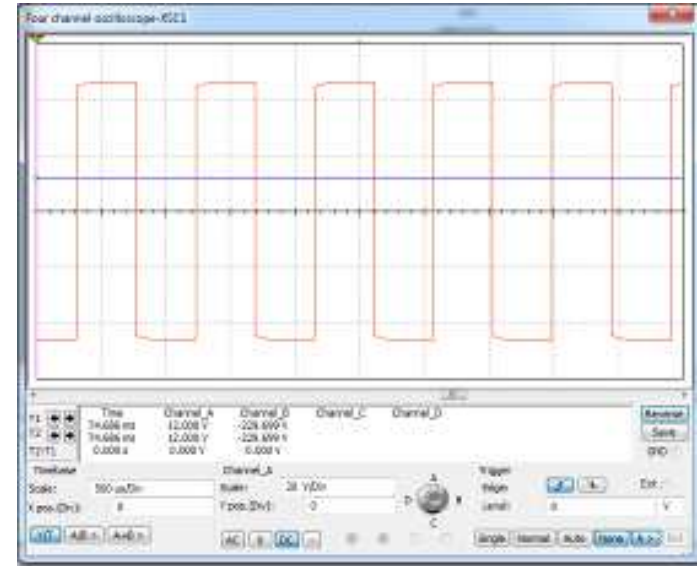

Figure6. Simulation Result of Square Wave Output of Inverter

\section{Recommendations}

Our research group needs to have connection to Government Society for practical works. The simulation results and experience results should compare and note to give conclusion. Another software as MATLAB can be checked for this proposed system. Moreover, battery charging circuit that can protect over charging and under charging can be further added in the original circuit. Hybrid with solar can be connected for this system. If so, more power beyond 450W can be drawn.

\section{Conclusion}

Though the electrification rate in Myanmar is one of the lowest in Asia, at 57\% in 2016, Myanmar Government aims to produce 2 percent of its electricity through renewable power in by 2020 and 9 percent by 2030. In this paper, 450 W wind power system in Pyay is discussed. The simulation results of voltage regulator and inverter are expressed. Though maximum supplied load of Pyay is now $72.06 \mathrm{MW}$ in 2018-19, it can be increased to $109.56 \mathrm{MW}$ in 2021-22. Renewable energy using is one of simple solutions. Rules and regulations should be limited in time before all projects that do not begin. Starting only one wind turbine should continue big wind farm for tourists' attraction in ancient town Pyay.

\section{References}

[1] Control of Wind Energy Output by using Impedance Source Inverter, Ph.D thesis, Zarchi San, 2017

[2] Floyd, Thomas L. Electronic devices : conventional current version / Thomas L. Floyd. - 9th ed.

[3] Google search

[4] J. L. Rodriguez-Amenedo, S. Arnalte, and J. C. Burgos, "Automatic generation control of a wind farm with variable speed wind turbines,"IEEE Transaction on Energy Conversion, vol. 17, no. 2, pp. 279-284, Jun. 2002.

[5] Renewable and Efficient Electric Power Systems, Gilbert M. Masters, Stanford University

[6] X. Wei, X. Qiu, J. Xu, and X. Li, "Reactive Power Optimization in Smart Grid With Wind Power Generator," in 2010 Asia-Pacific Power and Energy Engineering Conference, 2010, no. 2, pp. 1-4.

[7] Z. Chen, J. M. Guerrero, F. Blaabjerg, "A review of the state of the art of power electronics for wind turbines," IEEE Trans. Power Electronics, vol.24,no.8,pp.18591875, Aug 2009 